\title{
Electrical and microstructural characterization of Gd-doped Ceria/Y-doped Zirconia bi-layer electrolyte prepared by tape casting
}

\author{
Thiago Dias ${ }^{1}$, Dulcina Pinatti Ferreira de Souza ${ }^{2}$
}

\author{
${ }^{1}$ Faculdade Sudoeste Paulista - FSP, Avaré - SP - Brasil \\ thiagodiasmarte@yahoo.com.br \\ ${ }^{2}$ Programa de Pós Graduação em Ciência e Engenharia de Materiais - São Carlos, SP - Brasil \\ dulcina@ufscar.br
}

\begin{abstract}
GDC-YSZ bi-layer SOFC electrolytes are an interesting manner to protect GDC electrolytes of the low oxygen partial pressure present at anode-electrolyte interface. This oxygen partial pressure condition and high temperatures during the operation of SOFC permit GDC electrolyte reduction injuring the performance of SOFC. In this work, GDC-YSZ bi-layer electrolytes were prepared using double tape casting technique. Single layers of YSZ and GDC electrolytes were also prepared by the same technique for comparison. All samples were sintered at $1600{ }^{\circ} \mathrm{C} / 2 \mathrm{~h}$ in air and analyzed by SEM and impedance spectroscopy technique. A good adhesion was established between the layer GDC and YSZ and no cracks were detected despite the differential firing shrinkage. The electrical conductivity of GDC-YSZ bi-layer sample at $350{ }^{\circ} \mathrm{C}$ was $7.98 \times 10^{-5}$ S.cm ${ }^{-1}$ and for GDC and YSZ single layer samples electrical conductivities were $1.89 \times 10^{-4}{\mathrm{~S} . \mathrm{cm}^{-1}}^{\text {and }}$ $4.71 \times 10^{-5}{\mathrm{~S} . \mathrm{cm}^{-1}}$, respectively. These results show that GDC-YSZ bi-layer electrolyte is superior to YSZ single layer electrolyte.
\end{abstract}

Keywords: GDC-YSZ bi-layer electrolyte; tape casting; SOFC

\section{INTRODUCTION}

Currently, one of the main goals on solid oxide fuel cells (SOFC) technology is to achieve viable operation at temperatures lower than $1000{ }^{\circ} \mathrm{C}$, in which high cost materials are required to avoid the cell degradation [1-3]. Gadolinia-doped ceria (GDC) exhibits ionic conductivity higher than yttria-stabilized zirconia (YSZ) at temperatures below $800{ }^{\circ} \mathrm{C}$ and therefore present great potential for SOFC electrolytes applications [4,5]. However, the oxygen partial pressure at the interface between anode and electrolyte at $800^{\circ} \mathrm{C}$ is between $10^{-18}$ and $10^{-20}$ atm [6]. In these conditions, it occurs the $\mathrm{Ce}^{+4}$ reduction since at $800{ }^{\circ} \mathrm{C}$ the equilibrium oxygen partial pressure between $\mathrm{Ce}_{2} \mathrm{O}_{3}$ and $\mathrm{CeO}_{2}$ phases is $2.5 \times 10^{-20}$ atm. Consequently, under reducing atmosphere, GDC becomes a mixed conductor resulting in severe degradation of the cell performance [2,7]. Besides that, the reduction of ceria causes expansion of the crystal lattice decreasing the mechanical stability of the electrolyte [8].

An interesting manner to solve the reduction problems of GDC electrolyte for SOFC applications is the utilization of a thin layer of YSZ, which presents negligible electronic conductivity and high chemical stability in reducing environment, between GDC electrolyte and anode forming a bi-layer electrolyte. This electrolyte model has been suggested in order to block the electronic conductivity in the GDC layer, as well as increasing oxygen partial pressure in the GDC-YSZ interface, which improves the chemical stability of the doped ceria [9-13].

Virkar [14] was one of the first researchers to approach the issue of oxygen partial pressure in SOFC with bi-layer electrolytes. He proposed a simplified analytical model for calculating the oxygen partial pressure considering the conduction characteristics of the two layers as main parameters. Chan et al. [15] in a detailed paper, developed a model for bi-layer electrolyte for SOFC showing clearly the influence of the ratio between thickness of two layers, the effect of YSZ blocking layer and how bi-layer electrolyte design can improves the cell performance. Yahiro et al. [8] proposed a bi-layer electrolyte model showing that the deposition of a thin layer of YSZ on yttria-doped ceria (YDC) at anode side led to a significant increase in open circuit voltage and power density with respect to unprotected YDC electrolyte. 
Thermal stability of bi-layer electrolyte is ensured by the thermal compatibility between GDC and YSZ. The thermal expansion coefficients for 10 and $5 \mathrm{~mol} \%$ gadolinia-doped ceria is $11.5 \times 10^{-6}{ }^{\circ} \mathrm{C}^{-1}$ and $10.1 \times 10^{-6}$ ${ }^{\circ} \mathrm{C}^{-1}$, respectively, while for YSZ is $9.9 \times 10^{-6}{ }^{\circ} \mathrm{C}^{-1}[16]$.

The YSZ layer on the doped ceria electrolyte must be sufficiently thin to minimize its contribution to the total electrical resistance of the electrolyte due to low ionic conductivity of YSZ at intermediate temperatures. Liu et al. [17] produced GDC-YSZ bi-layer electrolyte $(7 \mu \mathrm{m} / 3 \mu \mathrm{m})$ on substrate of anode material using spray coating and obtained values of open circuit voltage close to the theoretical values showing the efficiency of YSZ layer in blocking the electronic conduction generated in the GDC layer.

The literature on GDC-YSZ bi-layer shows that performance improvements occur in relation to unprotected electrolytes. However, it is important to analyze the chemical compatibility between GDC and YSZ. The literature is somewhat controversial about the reactivity between the YSZ and GDC. Jang et al. [18] did not detect the formation of such undesired phases in bi-layer electrolyte sintered at $1400{ }^{\circ} \mathrm{C}$. Grover et al. [19] showed that formation of phases such as gadolinium zirconate, gadolinium cerate and zirconium cerate occurred in samples sintered at $1400{ }^{\circ} \mathrm{C} / 48 \mathrm{~h}$ from a mixture of $\mathrm{CeO}_{2}, \mathrm{ZrO}_{2}$ and $\mathrm{Gd}_{2} \mathrm{O}_{3}$. Tompsett et al. [20] found that the reactivity between YSZ and GDC is low and only three days after treatment at $1300{ }^{\circ} \mathrm{C}$ has been identified some signs of ionic diffusion.

Tape casting technique is indicated to obtain SOFC components because it is an excellent low cost technique to obtain thin flat ceramics [21,22]. In this work, tape casting technique was used to prepare GDCYSZ bi-layer electrolyte and single layer electrolytes of GDC and YSZ. Bi-layer electrolyte is discussed in relation to single layers electrolytes from impedance spectroscopy measurements and scanning electron microscopy analysis.

\section{MATERIALS AND METHODS}

The powder $10 \mathrm{~mol} \%$ gadolinia-doped ceria (GDC) was prepared mixing appropriate amount of cerium oxide and gadolinium oxide, both of high purity from Aldrich. The powder $8 \mathrm{~mol} \%$ yttria-stabilized zirconia (YSZ) was from Tosoh. Table 1 shows the amount of organic components used to prepare GDC and YSZ slurries. Ethanol and xylene were used as solvent, phosphate ester (Huntsman) as dispersant, polyvinyl butyral (PVB) Butvar B98 (Solutia) as binder. The plasticizers were triethylene glycol di-2-ethylhexanoate S2075 (Solutia) and polyalkylene glycol UCON 50HB2000 (Dow Chemical).

Table 1: Formulations of GDC and YSZ slurries prepared for single and double tape casting processes

\begin{tabular}{|c|c|c|c|c|c|}
\hline SLURRY & POWDER ( $\left(^{\mathrm{a}}\right)$ & SOLVENT $\left({ }^{a}\right)$ & DISPERSANT $\left({ }^{b}\right)$ & BINDER $\left({ }^{b}\right)$ & PLASTICIZER $\left({ }^{c}\right)$ \\
\hline GDC & 57.4 & $\begin{array}{l}\text { Ethanol: } 5.4 \\
\text { Xylene: } 37.2\end{array}$ & $\begin{array}{l}\text { Phosphate } \\
\text { Ester: } 0.8\end{array}$ & B98: 10.0 & $\begin{array}{l}\text { S2075: } 50.0 \\
\text { UCON: } 50.0\end{array}$ \\
\hline YSZ & 41.3 & $\begin{array}{l}\text { Ethanol: } 13.1 \\
\text { Xylene: } 45.6\end{array}$ & $\begin{array}{l}\text { Phosphate } \\
\text { Ester: } 0.8\end{array}$ & B98: 20.0 & $\begin{array}{l}\text { S2075: } 50.0 \\
\text { UCON: } 50.0\end{array}$ \\
\hline
\end{tabular}

$\left({ }^{a}\right): \%$ in relation to weight of powder + solvent; $\left({ }^{b}\right): \%$ in relation to weight of powder; $\left({ }^{c}\right)$ : in relation to weight of binder.

Slurries were vibratory milled in high-density polyethylene jars (Nalgene) and zirconia grinding media (Tosoh). Tape casting was performed in TTC-1200 tape caster (Richard E. Mistler, Inc.) equipped with a single blade. GDC-YSZ bi-layer tapes were prepared by double tape casting. First, YSZ tape ( $\sim 40 \mu \mathrm{m}$ thick) was casted and dried in air and then GDC tape ( $\sim 370 \mu \mathrm{m}$ thick) was casted on the YSZ layer forming a bilayer tape as illustrated at Figure 1. 


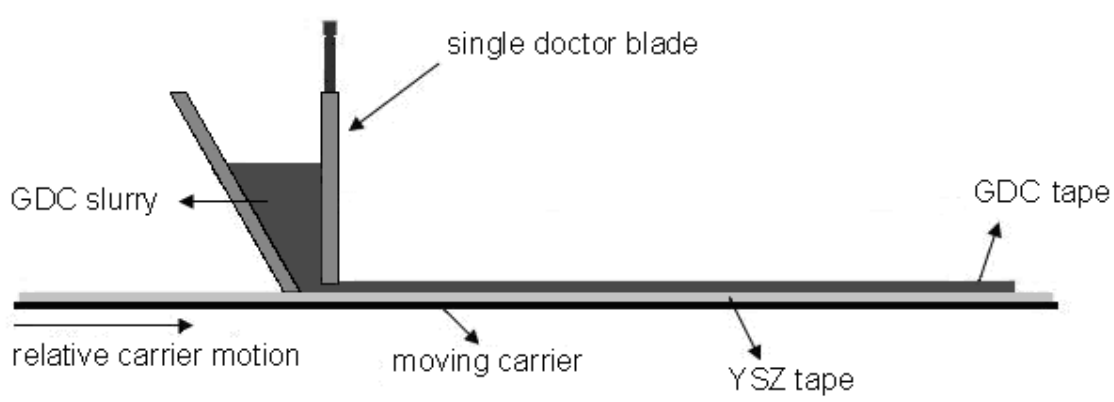

Figure 1: Scheme of double tape casting process used to prepare GDC-YSZ bi-layer tapes.

GDC and YSZ single layers were prepared from the same slurry formulations used for bi-layer tape. Thicknesses of dried GDC and YSZ tapes were measured with a micrometer and 600 and $430 \mu \mathrm{m}$, respectively were obtained. Disc samples of $20 \mathrm{~mm}$ diameter were cut from the dried tapes and sintered following a firing schedule with a heating rate of $30^{\circ} \mathrm{C} / \mathrm{h}$ up to $600^{\circ} \mathrm{C}$, followed by a heating rate of $300^{\circ} \mathrm{C} / \mathrm{h}$ up to $1600^{\circ} \mathrm{C}$, with a soak time of $2 \mathrm{~h}$. The sintered samples were characterized by impedance spectroscopy (HP $4192 \mathrm{~A}$ ) in a temperature range of $275-425^{\circ} \mathrm{C}$, frequency range of $5 \mathrm{~Hz}-13 \mathrm{MHz}$ and an applied voltage of $0.5 \mathrm{~V}$. The microstructure was analyzed by scanning electron microscopy (Phillips XL $30 \mathrm{FEG}$ ) on polished and thermally etched surfaces (bulk).

\section{RESULTS AND DISCUSSION}

\subsection{Microstructure}

Samples cut from the mono-layers of CGD and YSZ were sintered at $1600{ }^{\circ} \mathrm{C} / 2 \mathrm{~h}$ and both samples showed density higher than $98 \%$ of theoretical density and firing shrinkage of 25 and 30\%, respectively. Figure 2 shows the SEM micrographs of polished surface and thermally etched samples of GDC and YSZ. The mean grain size was $4 \mu \mathrm{m}$ for both samples.

Figure 2: SEM micrographs of polished and thermally etched sample of GDC and YSZ sintered at $1600{ }^{\circ} \mathrm{C} / 2 \mathrm{~h}$.
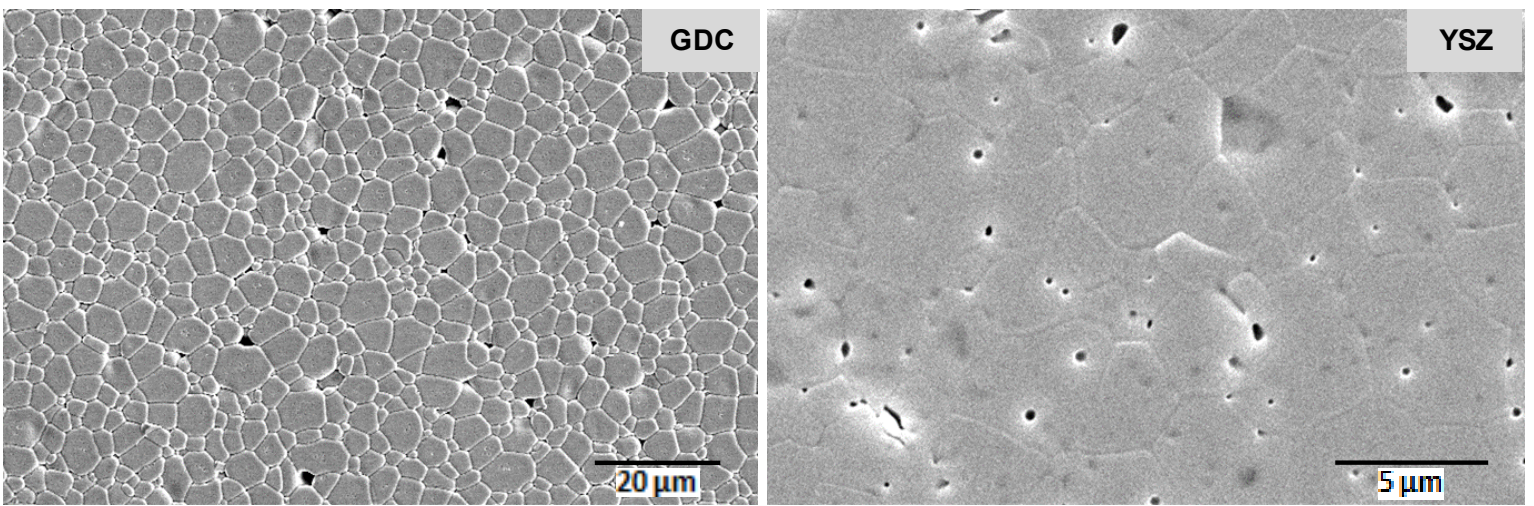
Figure 3 shows the bi-layer tape immediately after casting. Samples were cut from this tape and sintered at $1600{ }^{\circ} \mathrm{C} / 2 \mathrm{~h}$ in air. Figure 4 shows SEM micrographs of bi-layer fracture surface of sintered sample.

A good adhesion was established between the layer GDC and YSZ.

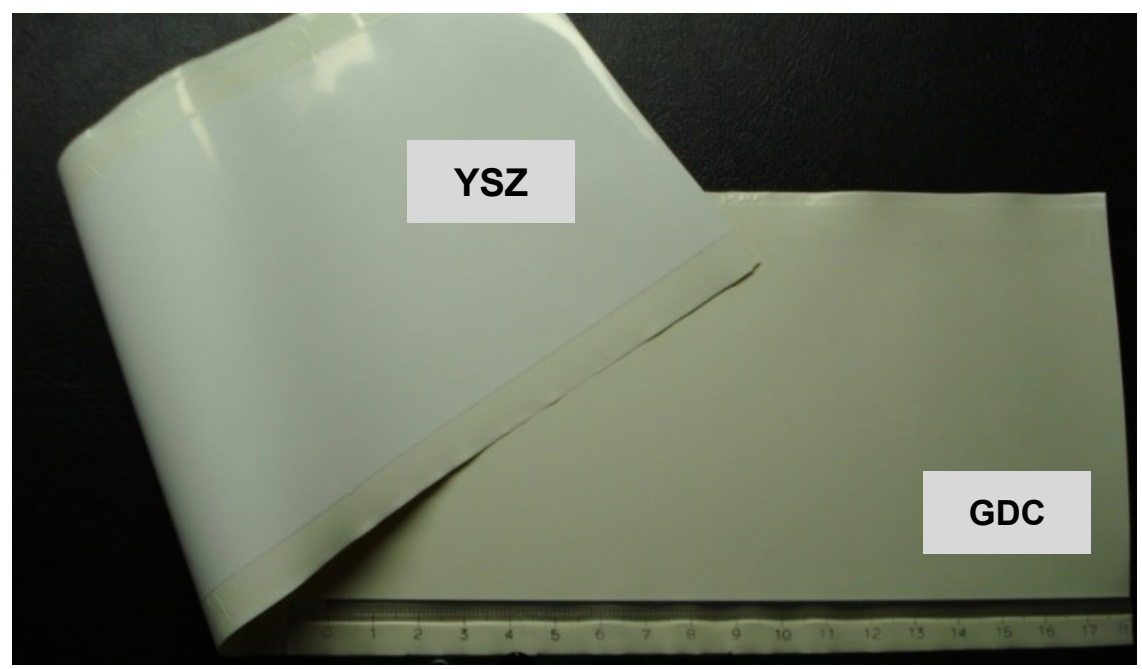

Figure 3: GDC-YSZ bi-layer tape after casting.

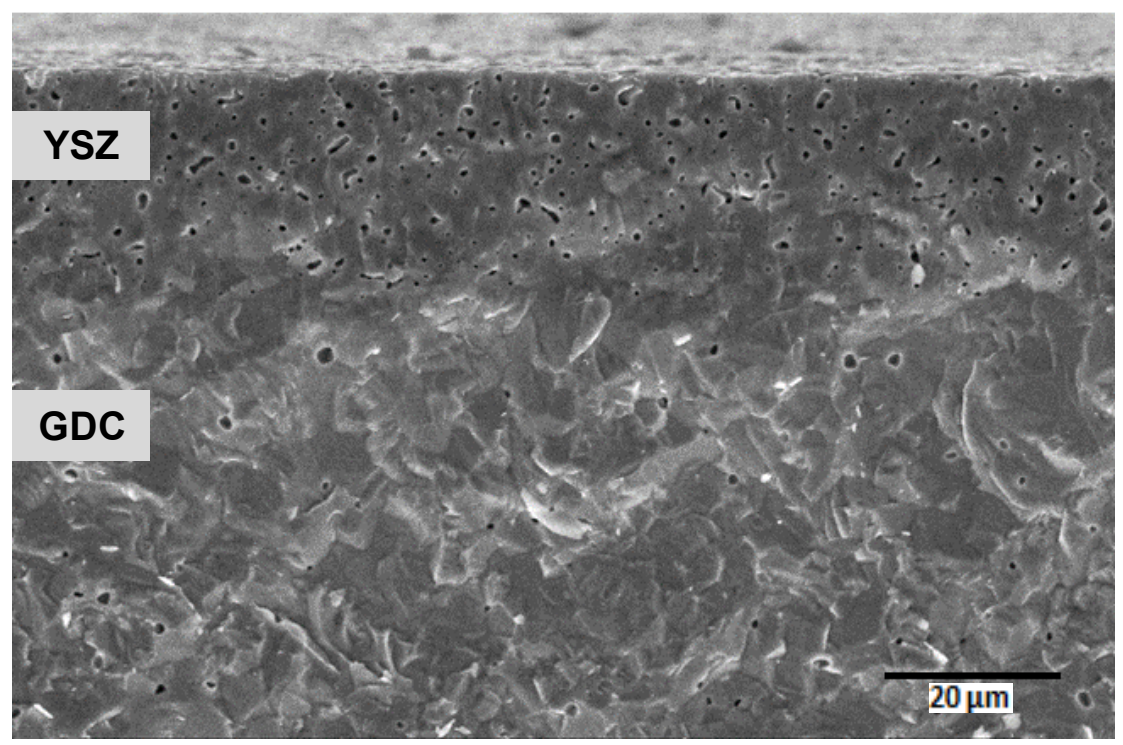

Figure 4: SEM micrographs of fracture surface of the GDC-YSZ bi-layer.

SEM analysis with high magnification of polished and thermally etched surface shows three important features on the interface: i) the presence of secondary phase on the GDC region with about $5.5 \mu \mathrm{m}$ of thickness, ii) denser layer on the YSZ region just above the secondary phase and iii) YSZ region with large porosity as shown Figure 5. The first two features can be attributed to chemical reaction between GDC and YSZ, as mentioned in the literature [18], generating an interface with peculiar microstructure. The third one can be explained in terms of differential firing shrinkage between GDC and YSZ layers. As mentioned above, single layer of GDC and YSZ showed firing shrinkage of 25 and $30 \%$, respectively, after sintering at $1600{ }^{\circ} \mathrm{C} / 2 \mathrm{~h}$, i.e. there is an important difference between firing shrinkages of materials that compose bi-layer sample. Firing shrinkage of YSZ is larger than GDC, but due to the coupling between two layers, the YSZ layer was prevented from reaching total shrinkage thereby limiting the elimination of porosity. Despite the differential 
shrinkage, no cracks were detected in the interface.

A comparison between the fracture surface showed in Figure 4 with polished and thermally etched surface showed in Figure 5, indicates that the GDC layer seems more porous in Figure 5. However, it is easy to note that size and shape of the many holes observed indicate that they were a result of pullout of small grains during the polishing step.

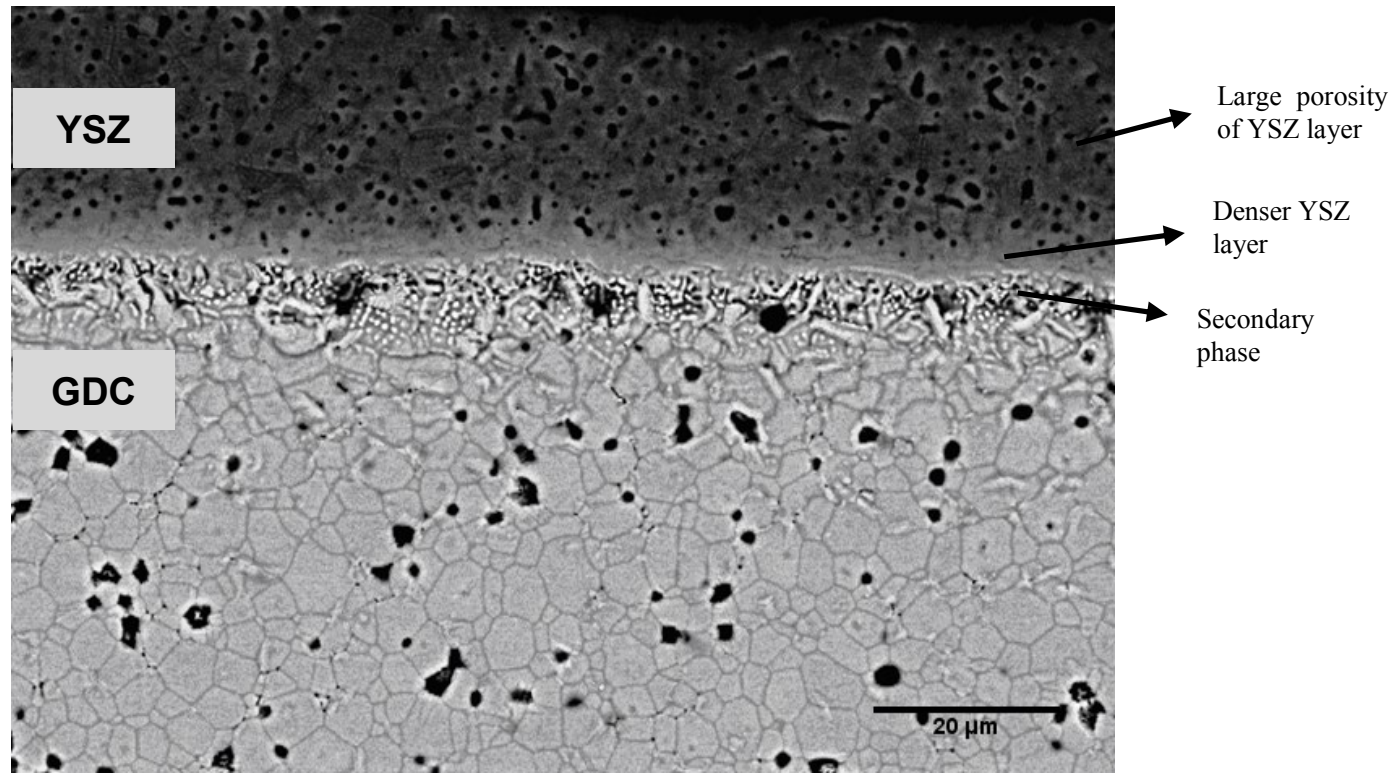

Figure 5: SEM micrographs of polished and etched surface of the GDC-YSZ bi-layer sintered at $1600{ }^{\circ} \mathrm{C} / 2 \mathrm{~h}$.

The existence of secondary phase at interface is undesirable because it can reduce the electrical performance of bi-layer electrolyte. Electrical conductivity measurements through impedance spectroscopy of bi-layer samples were done and a comparison with electrical performance of single layer samples was realized.

\subsection{Electrical conductivity}

The electrical characterization was carried out by impedance spectroscopy. Figure 6 shows the Nyquist plot measured at $400^{\circ} \mathrm{C}$ for sample GDC-YSZ bi-layer. The numbers marked on the curve correspond to the $\log _{10}$ of frequency. At intermediate frequencies, range there is a well-defined semi-circle with relaxation frequency of $10^{3} \mathrm{~Hz}$. At high frequencies range (Figure 6-b) it was observed that exist an overlapping of two or more contributions to total electrical resistivity. The sample used in this measurements is similar to that showed in Figure 5 with one platinum electrode on the YSZ surface and another on the GDC surface. One way to separate the sample contribution and electrode contribution for the impedance spectrum is the comparison between the electrical response of single layer samples, YSZ and GDC, with the response of the bi-layer sample. Figure 7 shows the comparison of all impedance spectra measured at $400^{\circ} \mathrm{C}$.

For GDC sample, the semi-circle due to the grain is no longer observed at $400^{\circ} \mathrm{C}$. Only the grain boundary contribution, with relaxation frequency of $10^{6} \mathrm{~Hz}$, and the electrode response are observed. For YSZ sample it is observed a semi-circle of grain response with relaxation frequency of $10^{6} \mathrm{~Hz}$ and a small response of grain boundary at $10^{4} \mathrm{~Hz}$. The thickness of GDC layer in the bi-layer sample represents approximately $85 \%$ of total thickness of sample and comparing GDC-YSZ bi-layer and GDC spectra it is possible identify similarities and to affirm that electrode response appear at $10^{3} \mathrm{~Hz}$ for both spectra. 


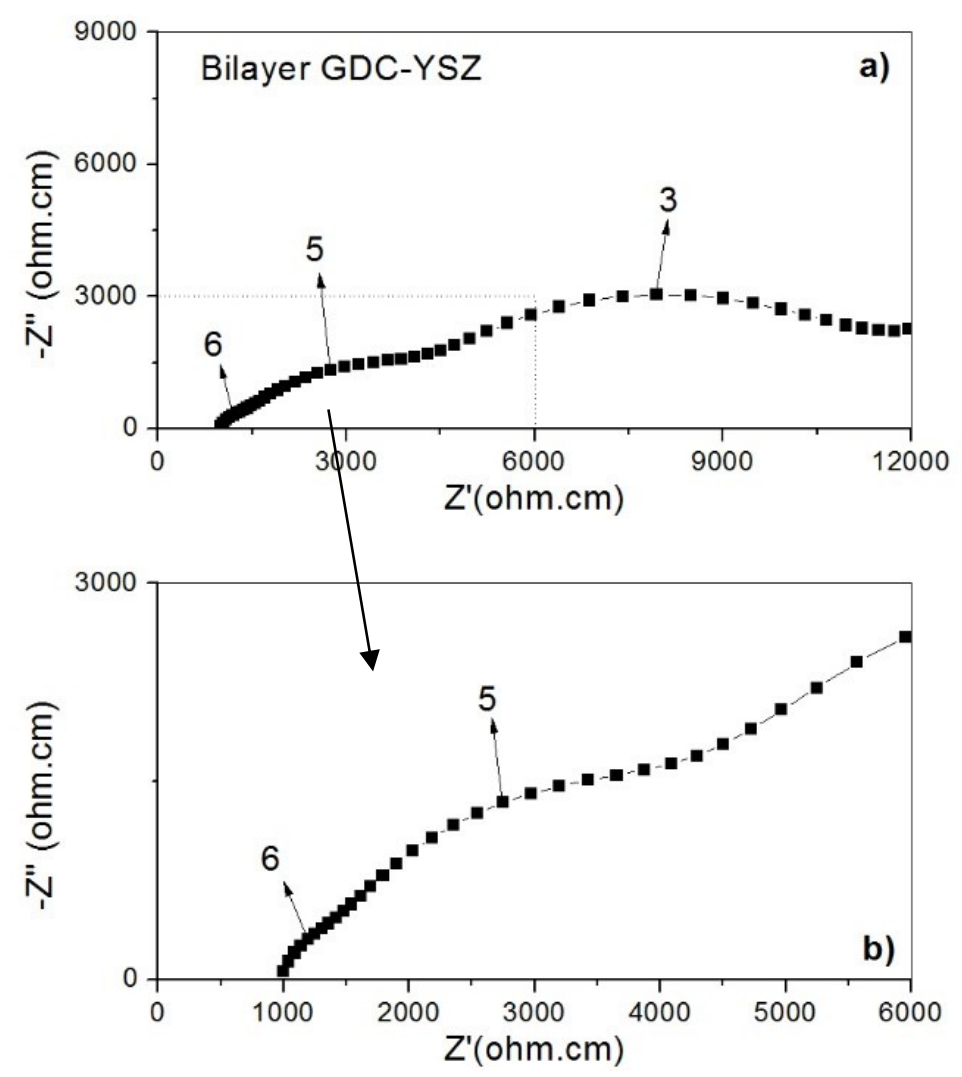

Figure 6: Nyquist plot of GDC-YSZ bi-layer sample measured at $400{ }^{\circ} \mathrm{C}$ : (a) complete frequency range; (b) high frequency range.

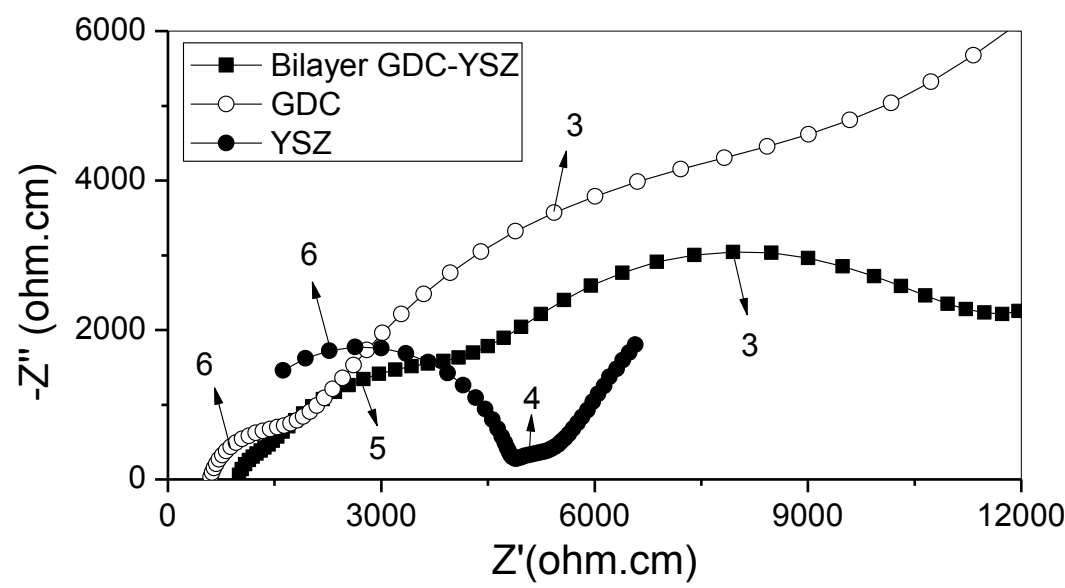

Figure 7: Impedance spectra of GDC and YSZ single layers and GDC-YSZ bi-layer measured at $400^{\circ} \mathrm{C}$.

The Arrhenius plots of total electrical conductivity of GDC, YSZ and GDC-YSZ bi-layer samples are shown in Figure 8. 


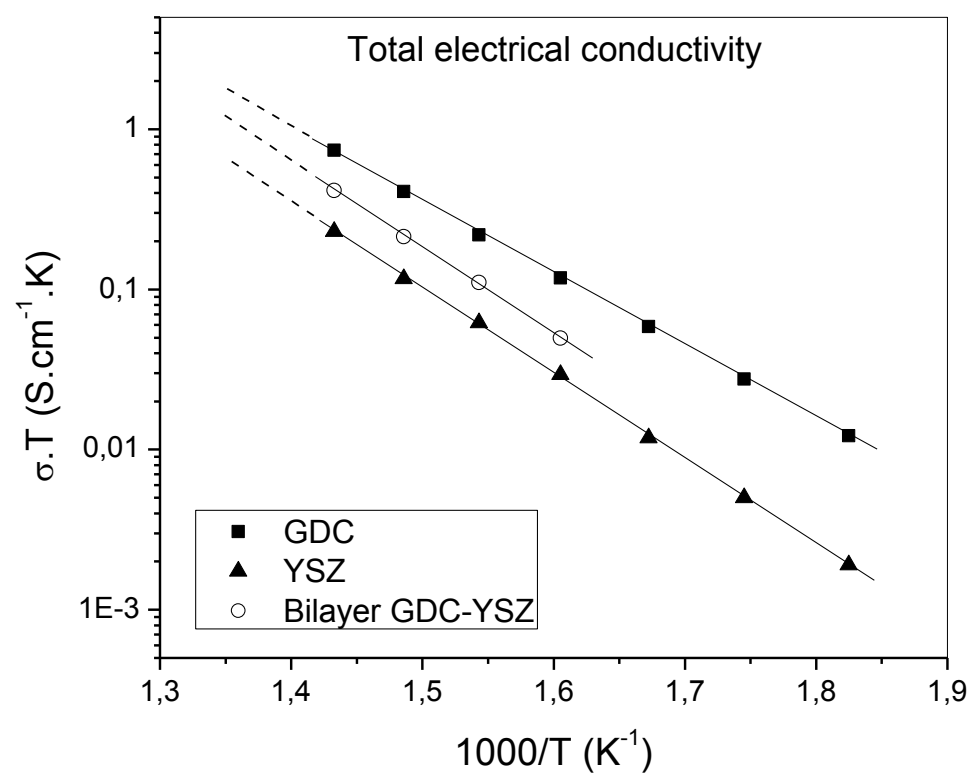

Figure 8: Arrhenius plot of total electrical conductivities for GDC-YSZ bi-layer sample and GDC and YSZ single layer samples sintered at $1600^{\circ} \mathrm{C} / 2 \mathrm{~h}$.

Despite the interface between GDC and YSZ, the electrical conductivity of bi-layer sample remained between conductivities of single layer samples. At $350{ }^{\circ} \mathrm{C}$, the electrical conductivity of GDC-YSZ bi-layer

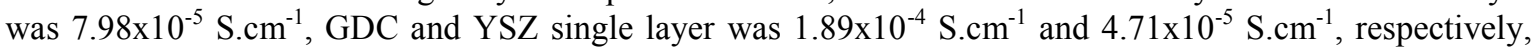
that are in agreement with the literature [23]. These results show the advantage of GDC-YSZ bi-layer electrolyte in relation to YSZ single layer.

\section{CONCLUSIONS}

GDC and YSZ mono-layer and GDC-YSZ bi-layer electrolytes were successfully obtained by the tape casting technique. The interface between the layers showed good adhesion and absence of cracks despite the differential firing shrinkage. Single layer samples of GDC and YSZ showed more densification than corresponding layers at bi-layer sample what can be attributed to the differential firing shrinkages of materials at bi-layer sample. The GDC-YSZ bi-layer sample was more conductive than YSZ single layer. Hence, from an electrical point of view, due to high ionic conductivity, the GDC-YSZ bi-layer electrolyte has a good potential for use in SOFC with advantages over traditional YSZ electrolyte.

\section{ACKNOWLEDGEMENT}

The authors acknowledge to CAPES and CNPq for the financial support and to Laboratory of Structural Characterization at DEMa/UFSCar for making available its infrastructure.

\section{BIBLIOGRAPHY}

[1] MAHATO, N., BANERJEE, A., GUPTA, A., et al., "Progress in material selection for solid oxide fuel cell technology: A review”, Progress in Materials Science, v.72, pp. 141-337, Feb 2015.

[2] KILNER, J. A., BURRIEL, M. "Materials for Intermediate-Temperature Solid-Oxide Fuel Cells", Annual Review of Materials Research, v. 44, pp. 365-393, Jul. 2014.

[3] TIETZ, F., BUCHKREMER, H.-P., STÖVER, D. "Components manufacturing for solid oxide fuel cells", Solid State Ionics, v.152-153, pp. 373-381, Dec 2002.

[4] STEELE, B. C. H. “Appraisal of Ce1-yGdyO2-y/2 electrolytes for IT-SOFC operation at $500{ }^{\circ} \mathrm{C}$, Solid State Ionics, v. 129, pp. 95-110, Mar. 2000

[5] ZHANGA, L., LIUA, F., BRINKMANB, K., et al, "A study of gadolinia-doped ceria electrolyte by electrochemical impedance spectroscopy”, Journal of Power Sources, v. 247, pp. 947-960, Sep. 2013. 
[6] FAES, A., HESSLER-WYSER, A., ZRYD, A. "A Review of RedOx Cycling of Solid Oxide Fuel Cells Anode", Membranes, v 2, pp. 585-664, Aug.2012.

[7] EGUCHI, K., SETOGUCHI, T., INOUE, T. "Electrical properties of ceria-based oxides and their application to solid oxide fuel cells", Solid State Ionics, v. 52, pp. 165-172, May 1992.

[8] YAHIRO, H., BABA, Y., EGUCHI, K., et al., "High Temperature Fuel Cell with Ceria-Yttria Solid Electrolyte", Journal of Electrochemical Society, v. 135, pp. 2077-2080, Aug. 1988.

[9] MARQUES, F. M. B., NAVARRO, L. M. "Performance of double layer electrolyte cells. Part I: Model behavior", Solid State Ionics, v. 90, pp. 183-192, Sep. 1996.

[10] MARQUES, F. M. B., NAVARRO, L. M. "Performance of double layer electrolyte cells Part II: GCO/YSZ, a case study”, Solid State Ionics, v. 100, pp. 29-38, Sep. 1997.

[11] TSAI, T., PERRY, E., BARNETT, S. "Low-temperature solid oxide fuel cells utilizing thin bi-layer electrolytes", Journal of Electrochemical Society, v. 144, pp. 130-132, Feb. 1997.

[12] YANG, S-H., CHOI, H-W. "Fabrication of YSZ/GDC Bilayer Electrolyte Thin Film for Solid Oxide Fuel Cells", Transactions on Electrical and Electronic Materials, v. 15, pp. 189-192, Aug. 2014.

[13] GAO, Z., ZENOU, V. Y., KENNOUCHE, D., et al, "Solid oxide cells with zirconia/ceria Bi-Layer electrolytes fabricated by reduced temperature firing", Journal of Materials Chemistry A, v. 3, pp. 9955-9964, Mar. 2015.

[14] VIRKAR, A. V. "Theoretical analysis of solid oxide fuel cells with two-layer, composite electrolytes: electrolyte stability", Journal of Electrochemical Society, v. 138, pp. 1481-1487, May 1991.

[15] CHAN, S. H., CHEN, X. J., KHOR, K. A. "A simple bi-layer electrolyte model for solid oxide fuel cells", Solid State Ionics, v. 158, pp. 29-43, Feb. 2003.

[16] KHARTON, V. V., KOVALEVSKY, A. V., VISKUP, A. P. "Oxygen transport in Ce0.8Gd0.2O2- $\delta$ based composite membranes”, Solid State Ionics, v. 160, pp. 247-258, Jun. 2003.

[17] LIU, Q. L., KHOR, K. A., CHAN, S. H., et al, "Anode-supported solid oxide fuel cell with yttriastabilized zirconia/gadolinia-doped ceria bilalyer electrolyte prepared by wet ceramic co-sintering process", Journal of Power Sources, v. 162, pp. 1036-1042, Nov. 2006.

[18] JANG, W. S., HYUN, S. H., KIM, S. G. "Preparation of YSZ/YDC and YSZ/CDG composite electrolytes by the tape casting and sol-gel dip-drawing coating method for low-temperature SOFC", Journal of Materials Science, v. 37, pp. 2535-2541, Jun. 2002.

[19] GROVER, V., TYAGI, "Phase relation studies in the CeO2-Gd2O3-ZrO2 system", Journal of Solid State Chemistry, v. 177, pp. 4197-4204, Nov. 2004.

[20] TOMPSETT, G. A., SAMMES, N. M., YAMAMOTO, O. "Ceria-Yttria-Stabilized Zirconia Composite Ceramic Systems for Applications as Low-Temperature Electrolytes", Journal of the American Ceramic Society, v. 80, pp. 3181-3186, Dec. 1997.

[21] TIMAKUL, P., JINAWATH, S., AUNGKAVATTANA, P. "Fabrication of electrolyte materials for solid oxide fuel cells by tape-casting", Ceramics International, v. 34, n.4, pp. 867-871, Mai. 2008.

[22] TIUNOVA, O. V., KHABAS, T. A., BREDIKHIN, S. I., et al, "Zirconia-based solid electrolyte obtained by tape casting", Inorganic Materials: Applied Research, v. 7, n.2, pp. 278-284, Mar. 2016.

[23] KHARTON, V. V., MARQUES, F. M. B., ATKINSON, A. "Transport properties of solid oxide electrolyte ceramics: a brief review”, Solid State Ionics v. 174, pp. 135-149, Out. 2004. 